\title{
Spectroscopic Analysis of Ancient Ceramic From Agror Valley Khyber Pakhtunkhwa, Pakistan
}

\section{Muhammad Zahoor ( $\nabla$ zahoormuhammad674@gmail.com ) \\ Hazara University Mansehra}

\section{Shakir Ullah}

Hazara University Mansehra

\section{Muhammad Abrar}

Hazara University Mansehra

\section{Tahir lqbal}

University of Gujrat

Abdul Hameed

Hazara University Mansehra

\section{Research article}

Keywords: LIBS, Elemental Analysis, Ceramic, Archaeometry

Posted Date: May 17th, 2021

DOl: https://doi.org/10.21203/rs.3.rs-510290/v1

License: (c) (1) This work is licensed under a Creative Commons Attribution 4.0 International License. Read Full License 


\section{Abstract}

The study of material remains has been very essential to reconstruct the past human lifestyle. Archaeologists use different scientific techniques to analyze the elemental composition of the material remains to locate the raw materials, to discover production sites and to understand ancient manufacturing technologies. Of these, Laser Induced Breakdown Spectroscopy (LIBS) method have been extensively used for the compositional analysis of different crystalline and non-crystalline materials of archaeological, historical and artistic interest for the last two decades. The present study was carried out to investigate the elemental composition of ceramic potsherds collected from the historic period. The present paper focuses on the major and minor elements identified through LIBS in the ceramic samples collected from different archaeological sites located in Mansehra, the easternmost district of Khyber Pakhtunkhwa Province of Pakistan. The LIBS results show the presence of $\mathrm{Fe}, \mathrm{Mg}, \mathrm{Ca}$, and $\mathrm{Na}$ as major elements in the ancient ceramic along with traces of Si, Ti, Al and K. LIBS results show differences in the concentration of each elements present in every selected ceramic potsherds which indicates the source of raw material, production strategies and time periods of these objects were related to each other.

\section{Introduction}

The study of ceramic is an important aspect of prehistoric and historic archaeology. Pottery was probably the first synthetic material [1] made by humans in the past and broken pottery fragments are among the most common artifacts found at most of the archaeological sites around the world.

The study of ancient ceramics provides valuable information about different aspects of past human behavior such as their trade and commerce, their rituals, technologies as well as exploitation of the resources [2]. The visual properties of ancient ceramic such as size, shape, and surface decoration are mostly used as cultural and chronological indicators. The chemical properties including texture of the paste (the clay and temper combination) help to understand their manufacturing techniques. This can also be used to locate the source and provenance of the objects. While oxidation state of iron-bearing constituents can be used to reconstruct firing conditions [3]. The primary purpose of compositional analysis of ceramics is to understand whether the objects were made locally or imported. The source of raw material i.e. clays and temper that do not overlap with the place of discovery also indicated in the compositional analysis of ceramic [4]. This can be obtained using the modern technology which is now playing an important role in the preservation, interpretation and promotion of archaeological objects [5].

Literature shows that various analytical techniques have been used extensively in study of archaeological objects. Of these, scanning electron microscopy (SEM) [6], X-ray diffraction (XRD) [7], X-ray fluorescence (XRF) [8], atomic absorption spectrometry (AAS), proton induced X-ray emission (PIXE) [9] inductively coupled plasma coupled to optical emission or mass spectroscopy (ICP-OES) [10] and Raman are among the most widely used techniques [11]. But the limitations of all these techniques are simple enough, sample preparation, land handling procedures, loss of originality and transportation of archaeological 
objects. These limitations were effectively covered by the recently developed technique Laser Induced Breakdown Spectroscopy (LIBS) [12].

Laser-induced breakdown spectroscopy, an elemental analysis technique is based on the characteristic emission of atomic lines emitted after laser ablation of selected sample [6]. The LIBS results of ancient Roman sculpture were also compared with other analytical techniques and it was found that LIBS is valid and accurate technique for quantitative analysis which can also be used for the studies of ancient jewelry [13]. Another important similar work has been carried out with LIBS analysis on a corroded bronze gun which was found on the Adriatic seabed and dated back to 16th to 17th century AD. [14]

The double-pulse LIBS also have been used for the analysis of ancient objects such as iron, copper-based alloys, and precious alloys found in water and provided suitable quantitative results [15]. Laser Induced Breakdown Spectroscopy has been applied ancient Roman pottery sherds recovered from different archaeological sites from Hispanic Terra Sigillata which was dated as 1 st to 5 th century AD. It is possible to classify the ceramic objects based on its location of production by looking at the element content and linear spectra correlation analysis [16]. The compositional analysis of ceramic sherds coming from eastern Turkey dated during the excavations process and dated back to Middle Iron Age by using laser induced breakdown spectroscopy [17].

Unfortunately, in Pakistan study on ancient pottery's compositional analysis have found in rare cases, so for only single article have found in which samples were collected from historic site of Aziz Dheri and the percentage of elements present in the samples measured by using different elemental techniques including, XRD, XRF and SEM etc.[18].

In current research, the elemental analysis of the ceramic potsherds collected from Agror Valley, Khyber Pakhtunkhwa province of Pakistan was carried out by the authors. The numbers of samples collected from each site are pieces of body sherds, rim sherds and the sherds from the base. The elemental analysis was performed using Laser Induced Breakdown Spectroscopy. The important features of LIBS which make it distinctive analytical technique includes its simple and easy process, availability of instruments which are easy to use, rapidity of analysis, analysis without any preparation of samples, capability of analysis to be perform on the site and the ability to analyze any type of material i.e. solid, liquid and gracious etc. analysis to be performed at the site. These features make LIBS, a more reliable technique for current study as compared to other techniques which are being used commonly in archaeological science for elemental analysis.

\section{Material And Methods}

\section{Area of Study}

The history of the valley as Agror Valley (Fig. 1) is not well known till the British came in the area. It might have been the sway of Abhisaries when Alexander invaded India. Many archaeological remains have been found around the ravines in neighbouring Tanawal Valley which are generally related to a side 
branch of commonly prevalent Buddhist Cultures in the region. This is testified with Shadore Inscription in the eastern side of the valley. It is an inscription in Khroshthi script on a rock reminiscent to one found at the Asokan Rock Edicts of Mansehra in adjacent Pakhli plain. During the visit of Hiuen Tsang in 630 $\mathrm{CE}$, it was probably the part of Urasha (Hazara) as his Man-ki-lu (Current Mangli Town between Mansehra and Abbottabad) lies very close to the Agror [19].The area was a subsidiary to Pkhali Plain under Mughals and in 17th or 8th century all of Hazara region saw great waves of invaders from the north, particularly Swatis came during this time [20]. Currently these Swatis are there as majority and elites. Khan of Agror (the ruler) during British time till the merging of the state into Pakistan was also a Swati. James Abbot, the first British Period officer and later Deputy Commissioner of Hazara District describes this area as an abode of large dacoit groups taking refuge here after raids in the surrounding valleys [21]. Barron Charles Hugel [22] also explains the same fear in the Sikh Period. British gave a detailed account of their skirmishes with the tribes of Tor Ghur, i.e. Akazai, Hassanzai, Chigharzai and Syeds which generally settled in Agror Valley [23].

\section{Archaeological Samples Selection}

The survey report [24] shows that the selected Archaeological sites as given in Table 1, based on architectures and some others features, are assigned to the historic period. Each site revealed large numbers of potsherd but single sample selected randomly from six historic site of the region. All the ceramic objects were recorded with initial description followed by the process of cleaning, labeling, detailed description and drawing properly before the analysis.

Table 1

Sample name and selected archeological sites with abbreviated names

\begin{tabular}{|llll|}
\hline S/No. & Selected Site Name & No. of Samples & Selected Sample's Accession No. \\
\hline 1 & Siddique Mound & 01 & SA03 \\
\hline 2 & Qalagai Mound & 01 & QA15 \\
\hline 3 & Chin Kot & 01 & CKA09 \\
\hline 4 & Titoli Mound & 01 & TTA23 \\
\hline 5 & Bela Mound & 01 & BA04 \\
\hline 6 & Tilla Mound & 01 & TA23 \\
\hline
\end{tabular}

\section{Siddique Mound}

With the elevation of $1129 \mathrm{~m}$ the site presents very fine collection of pottery including all general categories and types found in the area with the most interesting shards that is perforated as shown in Fig. 2.

\section{Qalagai Mound}


Locally the site is known as the place built by Prophet King Suleiman (A.S.) of Israelites. They say that he ordered giants to do the job. According to local tradition, Raja Salu attests the possibilities of ancient king's attack. There is a similar name of Raja Rasalu, a mythical king in Taxila region who fought demons/giants. He fought against does to subdue. Some large round stones are recognized in the local traditions as broken bangles of his sister while she was being kidnapped by giants. Similarly, some large/lengthy stones in the surrounding graveyards are said locally as his arrows. Pottery is very fine and includes rims bases handles body shards as shown below in the Fig. 3.

\section{Chinkot Mound}

The site is on a steep ridge accessible on foot from Dogai Bridge on Oghi - Shergargh Road. It is about a mile uphill toward south of Oghi with elevation of $1282 \mathrm{~m}$. The mound is detached and covered with modern houses and a large farm where thick pottery shards found abundantly on site and also eroded down into the gullies as shown in the Fig. 4. The ceramic shards include vessels, dishes on stand, ewers, bowls etc. Local population reported that the site along with some surrounding areas have been reported to have produced figurines, etc.

\section{Titoli Mound}

The site is located $1274 \mathrm{~m}$ from the sea level on attached mound (attached to the hill) at one side and rest surrounded by the farms. In the wheat crop a huge number of pottery shards found including rims, bases and pieces of long necked vessels as shown in Fig. 5. It is on the top of a steep mountain overlooking the Agror plain in Khabbal village. The site is stepped mound exposing remains of ruined walls all it's around.

\section{Bela Mound}

The site is located $1229 \mathrm{~m}$ above the sea level to the south of well-known Khroshthi Inscription site of Shahdore on a small spur leading uphill steeply, the newly discovered rock inscription of few Aksharas just to its east uphill. The site is badly disturbed as cut through by antiquity hunters. Pottery shards including channels, lugs, and bases rims found as shown in Fig. 6.

\section{Qalagia Mound}

It is on the top of a steep mountain overlooking the Agror plain in Khabbal village $1880 \mathrm{~m}$ above the sea level. It is accessible from a jeepable road (Pham Gali-Khabbal Road) which reaches at Nakkah in the north of this mound. From there one can walk a furlong to the south to reach here. The site is stepped mound exposing remains of ruined walls all around the mound. The surface is littered with pottery shards including bases, rims, and channels.

\section{Experimental Work}

\section{LIBS Setup}

The experimental arrangement consists of Nd: YAG laser and a LIBS 2000 detection system as shown in Fig. 8. The Nd: YAG Laser having pulse duration of $5 \mathrm{~ns}$ and repetition rate of $10 \mathrm{~Hz}$ is operated in the Q- 
Switch mode and capable of delivering $400 \mathrm{mj}$ at fundamental $(1064 \mathrm{~nm})$ and $200 \mathrm{~mJ}$ at second harmonic generation $(532 \mathrm{~nm})$. The laser is focused through a $20 \mathrm{~cm}$ focal length lens perpendicular to the target ceramic sample. The LIBS 2000 system consists of spectrometer covering range between 200-700 nm. The gate delay time and the gate width were optimized for single pulse (SP) experiments.

Laser pulse strikes the sample surface; it provides the energy to the constituent particles and ignites the plasma. Laser pulse energy exceeds the breakdown threshold of the sample surface the material becomes heated and ablated due to bonds breaking, evaporation and atomization. After laser ablation and vaporization the plasma plume is generated on a small spot. The nature of the plume and spot size depend on the laser parameters, atmospheric conditions and surface properties. The laser pulses emitted from Nd: YAG laser are deflected by using prism or mirror and focused on the sample through focusing lens having $75 \mathrm{~mm}$ of focal length. The spot size on the sample surface is comparable with diameter of laser beam that is $6 \mathrm{~mm}$ to $8 \mathrm{~mm}$. The sample is taken at the rotating stage at the front of focusing lens. The stage is a rotator system that provides the sample surface to the incident laser beam. The uniform rotation of stage provides the fresh surface for each time for better measurement.

Spectral lines are emitted from plasma; they are collected by collimating lens of $100 \mathrm{~mm}$ of focal length. The fiber optic cable is attached with the lens for the transmission of LIBS signal to the detection part. In the given detection system the Spectrometer has spectral resolution of $0.05 \mathrm{~nm}$. The delay time recorded for the data is $3.5 \mu \mathrm{s}$ and integration time is $2 \mathrm{~ms}$. The plasma light consisted of different wavelengths is dispersed and diffracted by spectrometer and detected by photo sensor with ICCD detector. The Delay generator is used for resolution of spectral lines. The LIBS signal is converted into electronic signal by using gating electronics. At the end the spectrum of atomic lines are obtained on computer screen in the form of spectrum.

\section{Calculation of Element's Concentration by Intensity Ratio Method}

For the analysis of elemental concentration in an ancient ceramic object, various analytical methods have been used such as calibration curve method, Calibration free method and Intensity Ratio Method etc. Intensity Ratio method is considered as a useful and rapid method for calculation through which major elements present in ancient ceramic objects can be observed. Therefore, for the under planned study line Intensity proportion technique have been utilized by taking the most extreme emanation force of a component in the example utilizing the accompanying equation. The convergence of a component is determined by most extreme power of a component over total of all the greatest forces of the considerable number of components of the example.

$\%$ concentration of Elements $=\frac{I_{\max }(\text { elements })}{\sum_{m}^{l} \max (\text { all })} \times 100$

\section{Results And Discussion}


Sample collected from all selected archaeological sites were subject to LIBS process in the laboratory where various strong emission lines of elements have been detected. Analysis of the samples show the presence of both high and low concentrated elements in the ceramics collected from Bela Mound (BA04), Titoli Mount (TTA23), Chinkot Mound (CKA09), Siddique Mount (SA03). In addition, these samples contain atomic lines of Calcium ( $\mathrm{Ca}$ ), Iron ( $\mathrm{Fe}$ ), Si (Silicon) and Sodium ( $\mathrm{Na}$ ) as key constituents and similarities in wavelength points, concentration and numbers of strong emission peaks that have close resemblance with each other as shown in Fig. 9.

For the analysis of elemental concentration in ancient ceramic objects the intensity ratio method is considered as a useful and rapid method. As the LIBS data revealed large number of spectra of the same elements in a sample, in this research only those lines are considered which have large intensity and can provide clear information as much as it can, as shown in Fig. 9. Each spectrum line in the selected sample has been verified by its wavelength with the help of National Institute of Standards and Technology (NIST) database.

The sample SA03 shows good amount of Iron ( $\mathrm{Fe})$, Magnesium (Mg), Sodium ( $\mathrm{Na}$ ) and Calcium (Ca), Silicon (Si), Titanium ( $\mathrm{Ti})$, Aluminum (Al) and Potassium (K). In this sample the leading concentration of Iron ( $\mathrm{Fe}$ ) with $18.43 \%$ concentration considered the dominant element. The concentration of $\mathrm{Na} 8.69 \%$ was calculated is this sample. The $19.01 \%$ concentration of Magnesium (Mg) observed in the same sample. $7.70 \%$ concentration of Silicon observed. Concentration of Titanium found $18.61 \%$ in almost all the samples but in this sample its concentration's graph is on its highest point. The concentration of Aluminum (Al) and Potassium (K) looks similar to each other. The graphs of Al with $3.07 \%$ and $\mathrm{K}$ with $8.99 \%$ have been shown in the Table 2 .

Table 2

Comparison of wavelength Points of Strong Emission Spectra with highest intensity for all Elements among the selected Sites

\begin{tabular}{|c|c|c|c|c|c|c|c|c|c|}
\hline \multirow[t]{2}{*}{ S.No. } & \multirow[t]{2}{*}{ Sample } & \multicolumn{8}{|c|}{ Elements Concentration (\%) } \\
\hline & & $\mathrm{Fe}$ & $\mathrm{Mg}$ & $\mathrm{Na}$ & $\mathrm{Ca}$ & Si & $\mathrm{Ti}$ & Al & \\
\hline 1 & BA04 & 518.42 & 517.26 & 589.27 & 445.66 & 288.15 & 441.72 & 537.13 & 404.72 \\
\hline 2 & CKA09 & 397.03 & 517.26 & 589.59 & 288.15 & 441.72 & 526.99 & 537.13 & 404.72 \\
\hline 3 & TTA23 & 396.31 & 517.26 & 427.36 & 335.03 & 252.85 & 455.54 & 232.15 & 404.72 \\
\hline 4 & SA03 & 671.03 & 517.26 & 427.36 & 527.02 & 288.15 & 455.54 & 274.80 & 404.72 \\
\hline 5 & QA15 & 518.42 & 517.26 & 588.99 & 335.03 & 288.15 & 440.76 & 537.13 & 404.72 \\
\hline 6 & TA23 & 518.42 & 517.26 & 589.88 & 527.02 & 559.79 & 521.03 & 257.53 & 693.87 \\
\hline
\end{tabular}

LIBS result demonstrates three major elements with the same concentration in sample CKA09. The concentration of $\mathrm{Fe}, \mathrm{Na}$ and $\mathrm{Mg}$ seems to be the same as $17.27 \%$ in this ancient ceramic potsherd reported from Chinkot Mound as shown in the Table 2. The fourth major element found in this sample is 
Calcium (Ca) with $14.20 \%$ concentration. The graph of Calcium (Ca) is closer to the other three major elements. Silicon (Si) also found with good quantity in this sample, $11.51 \%$ Si detected like other samples. The concentration of Titanium (Ti), Aluminum and Potassium also seems to be similar concentration have been found in this sample with minor difference.

The sample TTA23 shows leading concentration of Sodium ( $\mathrm{Na}$ ) with $29.02 \%$ percentage represent that $\mathrm{Na}$ was a major constituent while preparation of raw material for ceramic production. Iron ( $\mathrm{Fe}$ ) with $26.13 \%$ concentration to be very closer in the above graph. The $10.72 \%$ concentration of Magnesium $(\mathrm{Mg})$ observed in this sample which seems to be low percentage of $\mathrm{Mg}$ as compare to other samples. $13.91 \%$ concentration of Silicon also seems to be the highest percentage in all samples from selected sites. Concentration of Titanium found below $10 \%$ in almost all the samples but in this sample its concentration's graph is on its lowest point with $9.56 \%$ concentration. The concentration of Aluminum (Al) and Potassium (K) looks similar to each other. The graphs of Al with $4.74 \%$ and $\mathrm{K}$ with $4.09 \%$ have been shown in the Fig. 10.

Spectral analysis of BA04 contains different elemental composition such as, Calcium (Ca), $\mathrm{Fe}$ (Iron), $\mathrm{Si}$ (Silicon) and Sodium ( $\mathrm{Na}$ ) as key constituents and similarities in wavelength points, concentration and numbers of strong emission peaks have close resemblance with other samples from the selected sites. Like other selected samples from various archaeological sites with high altitude and latitude in District Mansehra elements such as Mg (Magnesium), Titanium (Ti), Aluminum (Al) and Potassium (K) have also been observed in the samples obtained from Bela Mound. The strong emission lines at various wavelength points have been detected in this sample with highest and lowest intensity. By looking as the concentration of the elements it is found that $\mathrm{Fe}, \mathrm{Mg}, \mathrm{Ca}$, and $\mathrm{Na}$ were the major ingredients for the ceramic production of selected region with good percentage as shown in Fig. 9. Other minor elements detected include $\mathrm{Si}, \mathrm{Ti}, \mathrm{Al}$ and $\mathrm{K}$ whose concentration varied from sample to sample. The concentration of two elements $\mathrm{Al}$ and $\mathrm{K}$ seems to be very low as compare to other elements but still their existence has been observed in every sample.

Figure 10 shows randomly selected samples which were used for the present research. In this table, the elemental concentrations of various elements are shown given. It is noticed that the concentration of elements is not the same in all the samples, which means during the production of ceramic objects of selected region, there was no concept of systematic selection of raw materials for ceramic production or it may also be assumed that the potters were not highly skilled rather they were following the traditional methods handed over to them from their ancestors.

Table 2 gives the comparative analysis of among the selected samples and the also in the wavelength of emission spectra collected with the help of spectrometer while the laser beam has been fallen on the selected sample. It is found that the emission line of $\mathrm{Mg}$ and $\mathrm{K}$ at the corresponding wavelength (Fe $518.42 \mathrm{~nm}$ and $\mathrm{K} 404.72 \mathrm{~nm}$ ) have been detected in all the samples. Three emission wavelength points of $\mathrm{Na}$ have been found in all the samples which are $588.59 \mathrm{~nm}, 427.36 \mathrm{~nm}$ and $285.00 \mathrm{~nm}$. In the case of Ca, five wavelength points can be seen where emission lines have been detected in all the selected samples. 
Emission lines of $\mathrm{Si}$ in all the samples noticed at three similar points i.e. $288.15 \mathrm{~nm}, 559.46 \mathrm{~nm}$ and $559.79 \mathrm{~nm}$.

\section{Conclusion}

The study was carried out to investigate the elemental composition of ceramic potsherds collected from the historic sites in district Mansehra KP, Pakistan. To investigate the major and minor elements present in the selected samples, Laser induced breakdown spectroscopy (LIBS) by using Nd: YAG laser at fundamental $(1064 \mathrm{~nm})$ and second $(532 \mathrm{~nm})$ harmonics was used. LIBS data revealed large number of spectrum of the same elements in a sample, here only those lines are considered which have huge intensity and can provide clear information. Each spectrum line was verified by its wavelength and intensity with the help of NIST database and also confirmed through Spectrum Analyzer, an instrument that graphically displays signal amplitude against frequency, in the frequency domain. It shows which frequency components are present in a signal and how strong these are. The intensity and wavelength of every peak have been recorded individually. The concentration of Iron ( $\mathrm{Fe})$, Magnesium (Mg), Sodium $(\mathrm{Na})$, Calcium (Ca), Silicon (Si), Titanium (Ti), Aluminum (Al) and Potassium (K) have been calculated in the selected samples. The constituents like $\mathrm{Fe}, \mathrm{Na}, \mathrm{Mg}$ and $\mathrm{Ca}$, Si indicates that these are the major elements that have been used in the production of analyzed ancient ceramic potsherds. The presence of Calcium in considerable amount in every sample reveals that the raw material for the production of ceramic objects in the selected region was composed of calcareous clay. The elemental analysis of selected samples provides information that all the shards belongs to same historic time period of the region and source of raw material for the production of ceramics objects is associated with surrounding Tanawal valley and Balakot valley as studied [25]. The elemental analysis can play vital role for the preservation of these archaeological ceramic housed in different museums in Pakistan.

\section{Declarations}

\section{Ethics approval and consent to participate}

Not applicable

\section{Consent for publication}

Not applicable

\section{Availability of data and materials}

The authors declare that the ceramic sherds analyzed here in this manuscript were selected from the collections of Archaeological survey by the Department of archaeology Hazara University Mansehra, Pakistan.

\section{Competing interests}


The authors declare that they have no they have no known competing financial interests or personal relationships that could have appeared to influence the work reported in this paper except the collection of analyzed material as discussed in the above section.

\section{Funding}

This work is initially supported by National Fund for Culture Heritage (NFCH), Ministry of Information, Broadcasting, National History \& Literary Heritage, Information and Broadcasting Division, Government of Pakistan, Islamabad, Pakistan.

\section{Author's Contributions}

The Writing and Editing of the Manuscript was completed by the author Muhammad Zahoor as part of his M.Phil thesis titled "Ancient Ceramic from Agror Valley (Mansehra): Elemental Analysis".

The author Shakirullah was a principal investigator of the Survey Project from which the analyzed ceramic sherds were selected for present study.

Author Abdul Hameed contributed in the result section and over all language correction of the manuscript also reviewed by him.

The experimental work was carried out under the supervision of the authors Muhammad Abrar and Tahir Iqbal at Sciemtific Laboratory Quaid-e-Azam University Islamabad, Pakistan.

\section{Acknowledgment}

Authors are grateful to Prof. Dr. Raheel Ali, Laser and Molecular Laboratory department of Physics Quaidi-Azam University, Islamabad Pakistan and Dr. Naveed Usman, Archaeological experimental Laboratory, Department of Archaeology Hazara University Mansehra KP, Pakistan for the use of the laboratory facility to perform the experiments. The authors also greatly acknowledged all concerns quarters for their technical and financial help to complete is research work.

\section{Authors' information}

1. Muhammad Zahoor (zahoormuhammad674@gmail.com) is currently enrolled in PhD program at the Department of Archaeology Hazara University Mansehra, Pakistan. He is working as a Research Associate in ongoing Project of Archaeological Excavations funded by Higher Education Commission Pakistan.

2. Shakirullah (arch@gmail.com) is currently working as Associate Professor at Department of Archaeology Hazara University Mansehra, Pakistan. He is the chairman of the department and working in various national and international Archaeological Projects as Principal Investigator.

3. Muhammad Abrar (mabrarphy@gmail.com) is currently working as Assistant Professor at Department of Physics Hazara University Mansehra. Pakistan. He in-charge of Devices simulation 
laboratory, in which, Plasma and solar cell devices are designed for laboratory use. He has the expertise to designed and operated liquid discharge and diagnosed for optimum condition. He also Industrial tools are processed for surface hardness using different sources such as DC, Pulsed DC, and RF source. He is working on also working plasma processing of foodborne and Diarrheal pathogens.

4. Tahir lqbal (tahirawan2@gmail.com) is an Assistant Professor of Physics in the Department of Physics at University of Gujrat. His main area of scientific interest is in Nano-photonics and Plasmonics, Nano-fabrication and Nano-characterization near-field optics, scanning probe microscopy, optical properties of metallic nanostructures and Nanotechnology.

5. Abdul Hameed (hameedarch2014@gmail.com) is is currently working as Assistant Professor at Department of Archaeology Hazara University Mansehra. He is specialist in Buddhist Archaeology of South Asia.

\section{References}

1. Hughes CO. \& Michael. (2013). Pottery in Archaeology. New York: Archaeometry, Journal of Archaeological Science, Studies in Conservation, Medieval Archaeology, Medieval Ceramics and Oxford Journal of Archaeology, among others.

2. Nichols LJ. (2010). The Study of Prehistoric Pottery; General Policies and Guidelines for analysis and publication. Wessex Archaeology. The prehistoric Ceramics Research Group 1997.

3. Glascock HN. Instrumental Neutron Activation Analysis and Multivariate Statistics for Pottery Provenance. 2. Tacoma: Pacific Lutheran University; 2004. USA: Kluwer Academic Publishers. Printed in the Netherlands.

4. Shankar Rai NK. (2015). Rare Earth Elements Analysis in Archaeological Pottery by Laser Induced Breakdown Spectroscopy. An International Journal for Rapid Communication, 03-04.

5. Pankaj Singh PS. (2017). A study of archaeological pottery of Northeast India using laserinduced breakdown spectroscopy (LIBS). Journal of Cultural Heritage.

6. Spoto G, T. A. (2000). Probing archaeological and artistic solid materials by spatially resolved analytical techniques. Journal of the American Chemical Society, 429-439.

7. Moens L, v. B. X-ray fluorescence. In: Winefordner JD, editor. Modern analytical methods on analytical chemistry and its applications. New York: Wiley; 2000.

8. Schreiner M, F. B.-S. (2004). X-rays in art and archaeology; an overview. Journal of powder diffraction, 3-11.

9. Dran J-C, C. T. (2000). Particle-induced X-ray emission. In: Wine fordner JD, editor Modern analytical methods in art and archaeology, Chemical analysis, a series of monographs on analytical chemistry and its applications (Vol. 155). Wiley New York.

10. Khedr A, M. H. (2013). In-depth micro-spectrochemical analysis of archaeological Egyptian shards. Journal of Applied Physics, 835-842. 
11. Madkour HI. (2015). Elemental Analysis Study of Glazes and Ceramic Bodies from Mamluk and Ottoman Periods in Egypt by Laser Induced Breakdown Spectroscopy (LIBS). An International Journal of Mineralogy, Crystallography, Geochemistry Ore Deposits, Petrology, Volcanology and applied topics on Environment, Archaeometry and Cultural Heritage, 108-109.

12. Rosalba OD. (2010). Laser Induced Breakdown Spectroscopy for Elemental Analysis in Environmental, Cultural Heritage and Space Applications: A Review of Methods and Results. Sensors, 7434-7435.

13. Bolognesi L, C. M. (1999). Calibration-free laser induced plasma spectroscopy for cultural heritage conservation and analysis. 2nd International Congress on Science and Technology for the Safeguard of Cultural Heritage in the Mediterranean basin, (pp. 431-436). Elsevier, Paris.

14. Corsi M, C. G. Archaeometric analysis of ancient copper artefacts by laser-induced breakdown spectroscopy technique. Microchim Acta. 2005;152:105-11.

15. Giacomo DM. Double pulse laser produced plasma on metallic target in seawater: basic aspects and analytical approach. Spectrochim Acta. 2004;59:1431-8.

16. Lopez AJ, N. G. LIPS and linear correlation analysis applied to the classification of Roman pottery Terra Sigillata. Appl Phys A. 2006;83:695-8.

17. Erdem ÇG. (2008). Characterization of Iron age pottery from eastern Turkey by laser-induced breakdown spectroscopy (LIBS). Journal of Archaeological Science, 2486-2487.

18. Muhammad M. (2009). Scientific Analysis of Pottery from Aziz Dheri (Gandhāra). Gandharan Sudies, 131-132.

19. Beal S. SI-YU-KI-Buddhist Records of the Western World. London: Trübner \& Co., Ludgate Hill; 1884.

20. Caroe O. The Pathan 550 B.C.-A.D. 1957. London: Macmillan \& Co. Ltd.; 1965.

21. Allens C. (2001) Soldier Sahibs: The Adventurer who made the North West Frontier, Abacus, London.

22. Hügel BC. (1840). Trevels into Punjab and Kashmir, London.

23. Watson HD. Gazetteer of the Hazara District 1907, N.W.F. Provence District Gazetteers: Volume I.A. Hazara District. London: Chatto \& Windus; 1908. Edt ) ) .

24. Ali I, Shah I, Hameed A, Ashfaq A, Tahir M. (2011). Archaeological Exploration in Balakot, District Mansehra 2006-07: A preliminary Report, Pakistan Heritage, Vol.3: 149-160, Mansehra: Research Journal of the Department of Archaeology, Hazara University, Mansehra.

25. Usman N, Shakirullah, Rashid A. (2019), Microstructural Analysis Of Potsherds From Archaeological Explorations Of The Kaghan Valley, Mansehra, Pakistan, Journal of the Research Society of Pakistan Vol. 56, Issue No. 2.

\section{Figures}




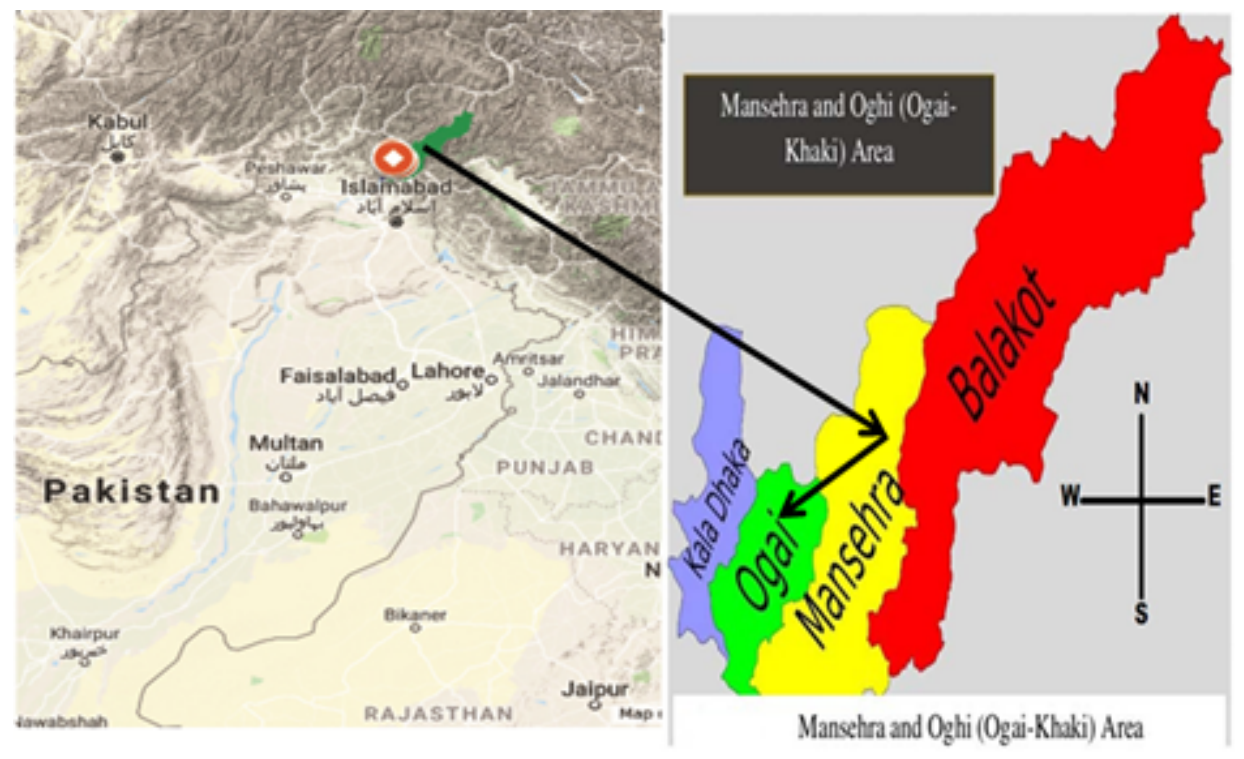

\section{Figure 1}

Area of sample collection Note: The designations employed and the presentation of the material on this map do not imply the expression of any opinion whatsoever on the part of Research Square concerning the legal status of any country, territory, city or area or of its authorities, or concerning the delimitation of its frontiers or boundaries. This map has been provided by the authors.

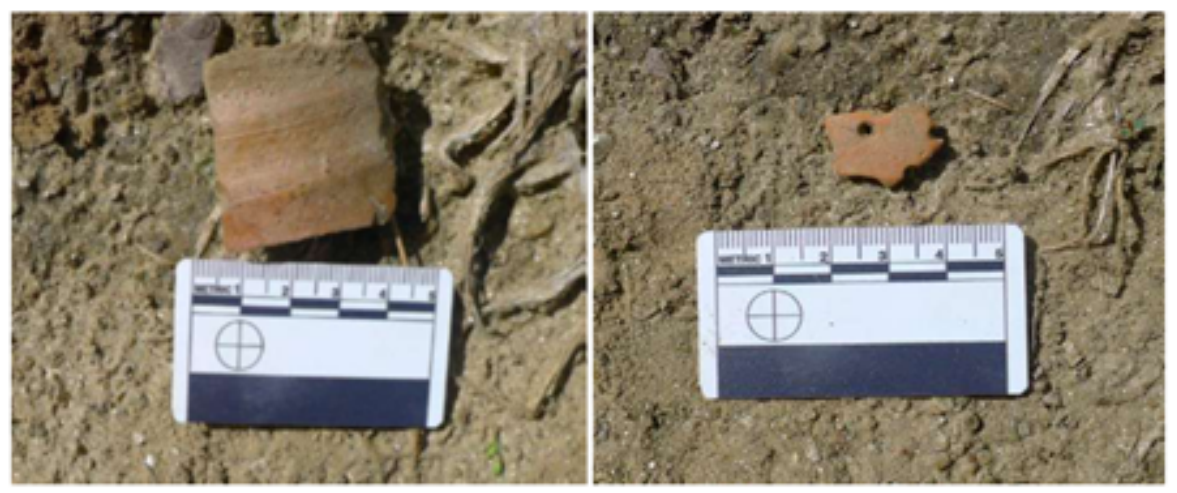

Figure 2

Analyzed sample from Siddique Mound with primary context
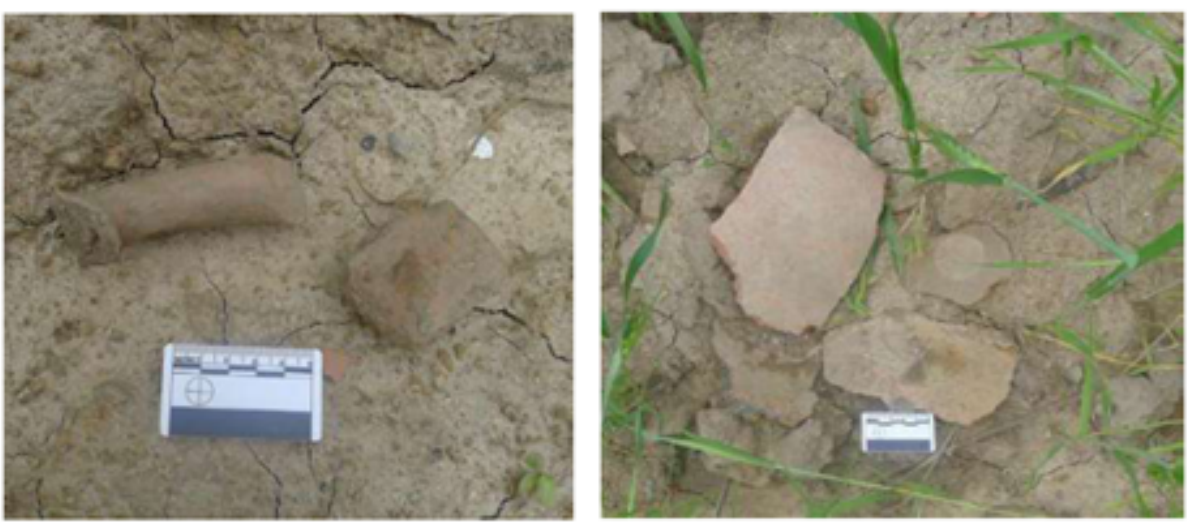
Figure 3

Analyzed Sample from Qalagai Mound
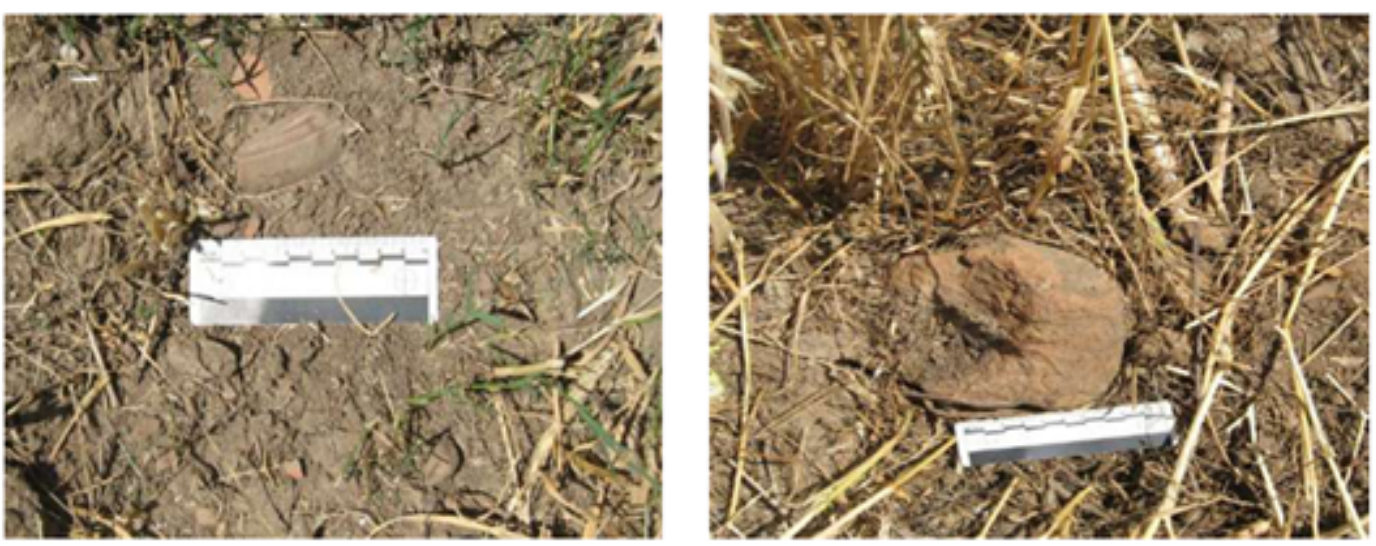

Figure 4

Analyzed Sample from Chinkot Mound
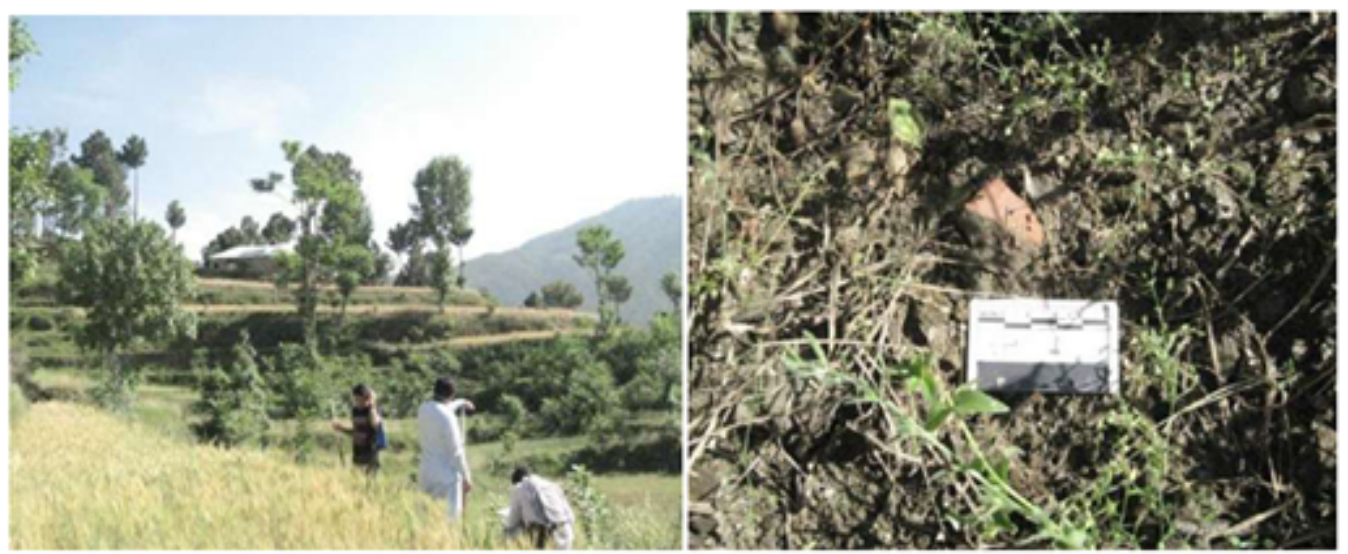

\section{Figure 5}

Analyzed Sample from Titoli Mound
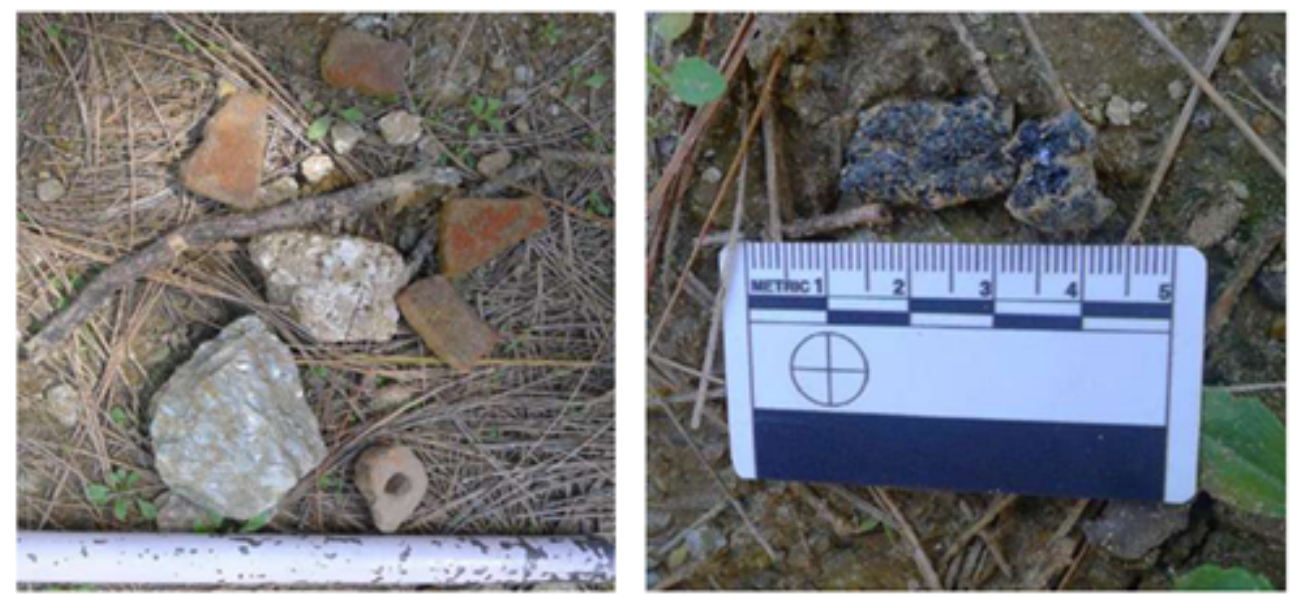
Figure 6

Analyzed Sample from Bela Mound
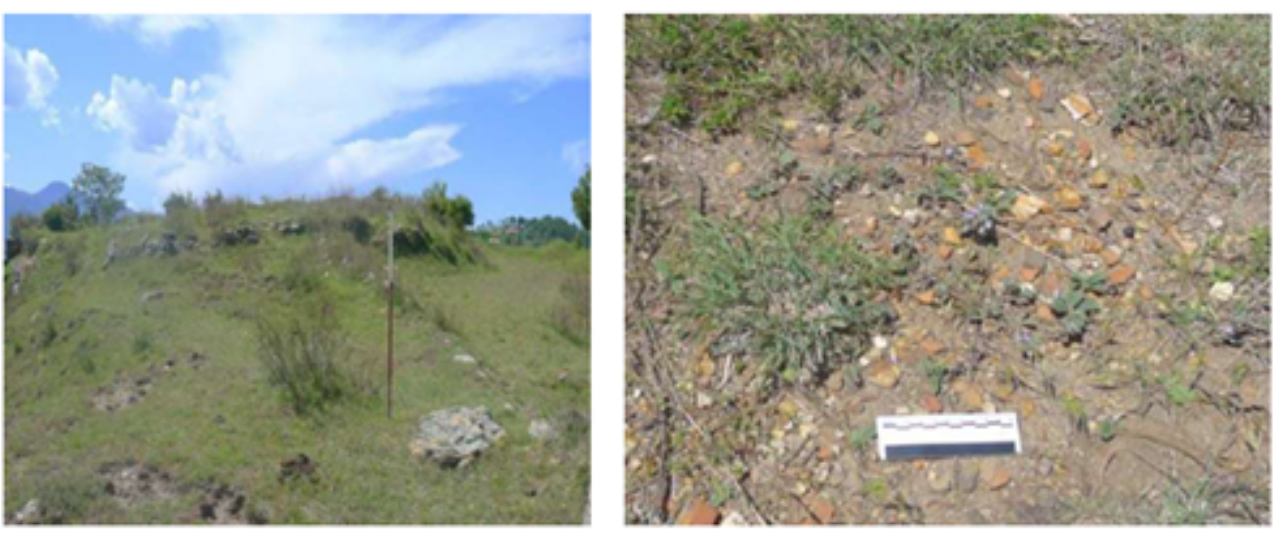

Figure 7

Analyzed Sample from Qalagai Mound

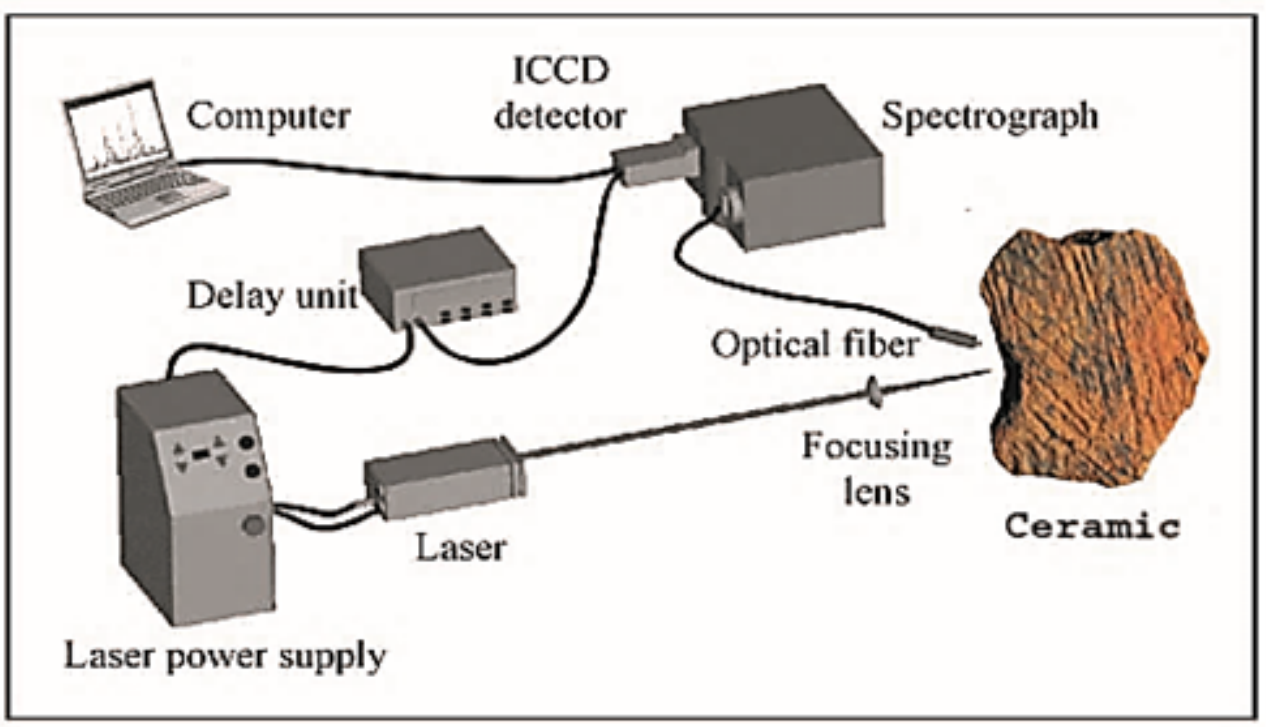

Figure 8

Step by Step analysis of solid ancient ceramic potsherd using LIBS 

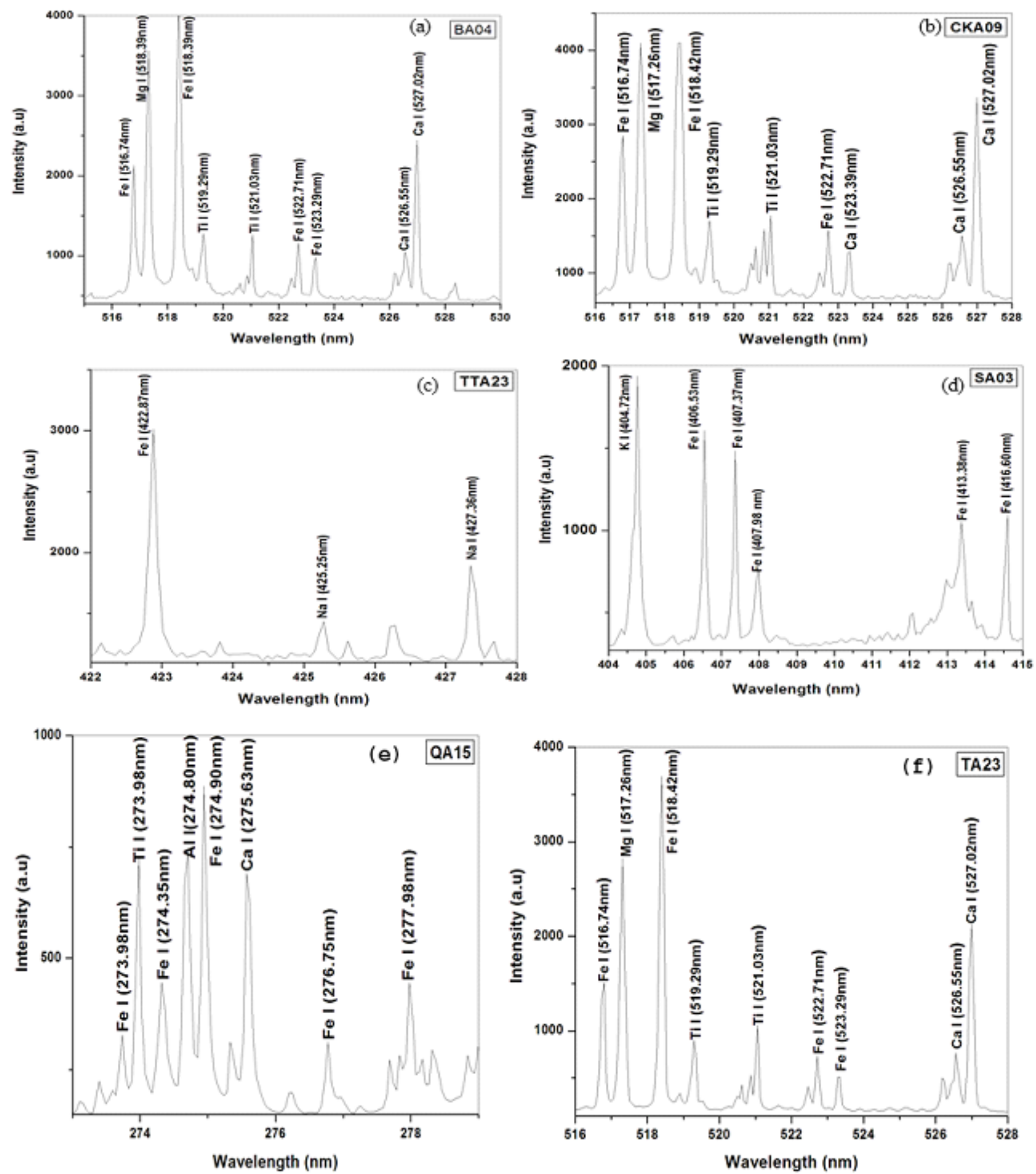

Figure 9

Spectral Analysis of the (a) BA04, (b) CKA09 (c) TTA 23, (d) SA03, (e) QA15, (f) TA23 

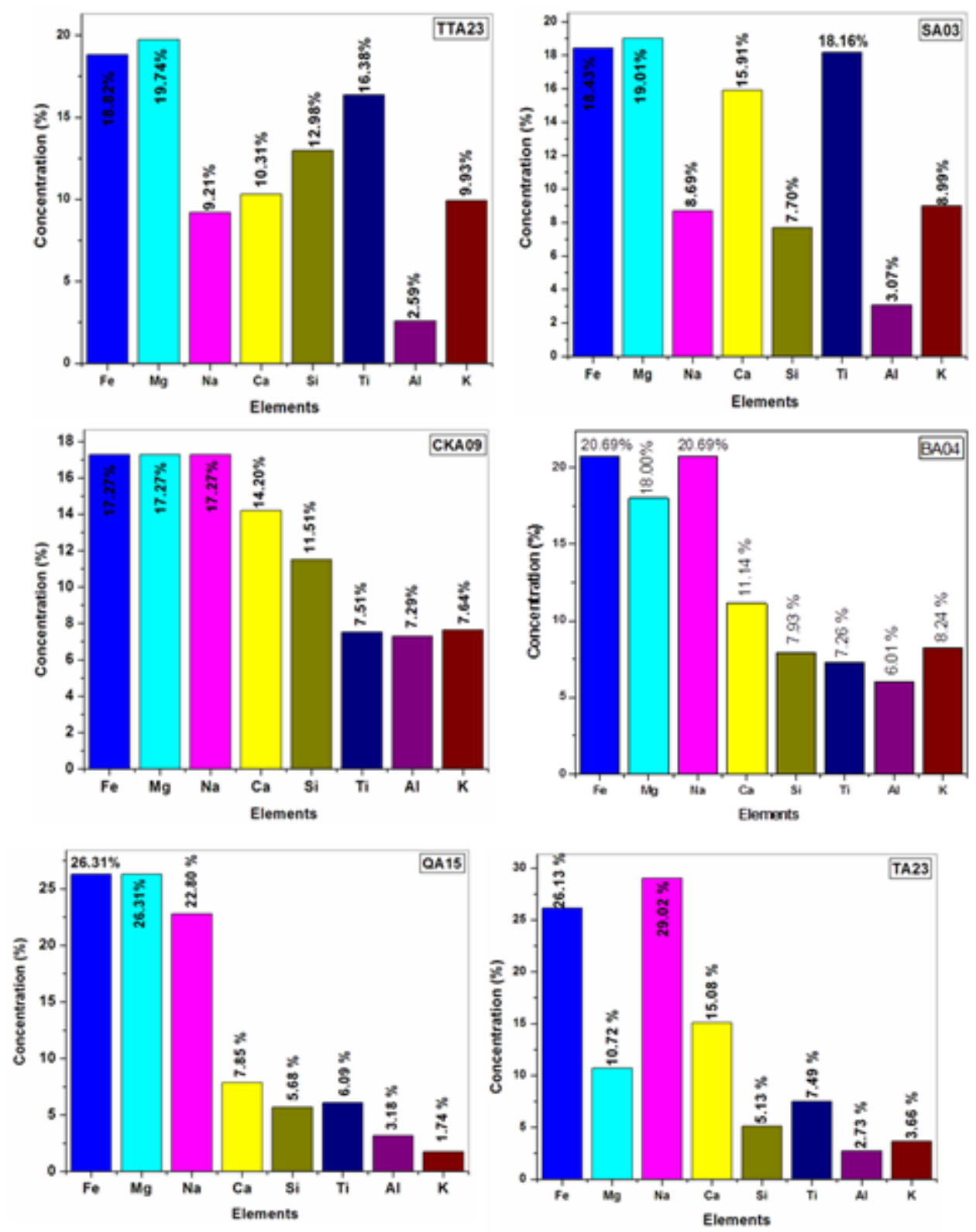

Figure 10

LIBS results of selected samples 